\title{
Hybrid Nd-Fe-B/barium ferrite magnetic materials with epoxy matrix
}

\author{
Aleksandar P. Stajčić ${ }^{1}$, Jasna T. Stajić-Trošić ${ }^{1}$, Aleksandar S. Grujić ${ }^{1}$, Mirko Z. Stijepović ${ }^{2}$, Nada L. Lazić ${ }^{4}$, \\ Tomáš Žák ${ }^{5}$, Radoslav R. Aleksić ${ }^{3}$ \\ ${ }^{1}$ University of Belgrade, Institute of Chemistry, Technology and Metallurgy, Belgrade, Serbia \\ ${ }^{2}$ Texas A\&M University at Qatar, Department of Chemical Engineering, Qatar \\ ${ }^{3}$ University of Belgrade, Faculty of Technology and Metallurgy, Belgrade, Serbia \\ ${ }^{4}$ Institute of General and Physical Chemistry, Belgrade, Serbia \\ ${ }^{5}$ Institute of Physics of Materials AS CR, Brno, Czech Republic
}

\begin{abstract}
Lately, there has been great attention paid to the research of bonded hybrid composites with improved dynamic mechanical capacities capable of replacing bonded $\mathrm{Nd}-\mathrm{Fe}-\mathrm{B}$ magnetic materials, by using cheaper (ferrite) materials instead of the $\mathrm{Nd}-\mathrm{Fe}-\mathrm{B}$ powder while retaining the satisfying values of the maximum magnetic energy. The objective of this study is to assess how different contents of $\mathrm{Nd}-\mathrm{Fe}-\mathrm{B}$ and/or barium ferrite particles can affect morphological, dynamic mechanical and magnetic properties of bonded composite materials. The interactions between employed magnetic powders and the interactions between magnetic powders and polymer binder are considered. For the examination of the magnetic behaviour, a vibrating sample magnetometer (VSM) is used. Different shapes and sizes of the obtained hysteresis loops are used for comparison and prediction of the polymer bonded materials properties. The homogeneous distribution of the magnetic particles in the polymer matrix is validated using scanning electron microscopy (SEM). The elastic and damping behavior examined by dynamic mechanical analysis (DMA) show improved properties for hybrid composite materials.
\end{abstract}

Keywords: Nd-Fe-B, composites, bonded magnets, DMA, VSM.

\section{SCIENTIFIC PAPER \\ UDC 66.017:669.055}

Hem. Ind. 66 (3) 301-308 (2012)

doi: 10.2298/HEMIND111104098S

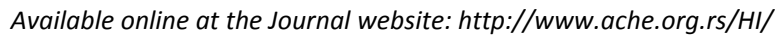

The nanocrystalline $\mathrm{Nd}-\mathrm{Fe}-\mathrm{B}$ alloys are among the most superior magnetic materials with high value of maximum energy product (approx. 50 MGOe) [1]. Besides high values of the remanence and coercivity, as well as their relatively high Curie temperatures (approx. $312{ }^{\circ} \mathrm{C}$ ) [2] these types of magnetic alloys are identified as suitable for research and further development of magnetic composite materials with polymer matrix, so called bonded magnets [3]. Contemporary research in the field of magnetic composite materials on the basis of $\mathrm{Nd}-\mathrm{Fe}-\mathrm{B}$ alloys are directed into several directions: increase of magnetic energy [4], meaning optimization of magnetic capacities; improving corrosion resistance [5]; optimization of production process, i.e., of process parameters; reduction of the subtle rare earth content $(\mathrm{Nd})$, targeting towards decreasing the price of the final magnetic material while keeping high values of the maximum magnetic energy. Application of various process techniques in the production process of bonded magnets gives the possibility for utilization of various magnetic powders in combination with different polymeric materials as binding agent [6-8]. Advantages

Correspondence: A. Grujić, Institute of Chemistry, Technology and Metallurgy, University of Belgrade, Njegoševa 12, 11000 Belgrade, Serbia.

E-mail: gruja@tmf.bg.ac.rs

Paper received: 4 November, 2011

Paper accepted: 18 November, 2011 of the using bonded composite materials include their simple technology, possibility of tuning their final properties, low manufacturing costs (as no costly finishing is necessary), and low material losses (due to a simple forming of any shape).

The amount of $\mathrm{Nd}-\mathrm{Fe}-\mathrm{B}$ powder in the bonded magnet plays a crucial role in determining magnetic properties. A higher content of $\mathrm{Nd}-\mathrm{Fe}-\mathrm{B}$ powder usually results in a higher remanence magnetization, $B r$, and maximum energy product, $B H_{\max }$, and therefore it is desirable from the magnetic perspectives. However, a higher content of magnetic filler may change the rheology of polymer melt during the process, and so subsequently impact the mechanical strength of bonded magnets $[9,10]$. The strong influence of relatively small amounts of filler particles on the dynamic mechanical properties of composites has significantly contributed to increased use of polymer materials in many commercial applications. The presented study is undertaken with intention to investigate the effect of different filler content on the dynamic mechanical and magnetic properties of the $\mathrm{Nd}-\mathrm{Fe}-\mathrm{B}$ and/or barium ferrite composite materials.

\section{EXPERIMENTAL}

Rapid quenched $\mathrm{Nd}-\mathrm{Fe}-\mathrm{B}$ magnetic powders with stoichiometric neodymium content $\left(\mathrm{Nd}_{11.7}(\mathrm{Fe}, \mathrm{Co})_{80} \mathrm{~B}_{8.3}\right)$ 
and particle size from 74 to $177 \mu \mathrm{m}$ are employed as magnetic filler for polymer composite magnets manufacturing. Hybrid magnetic composites are produced by replacing the part of $\mathrm{Nd}-\mathrm{Fe}-\mathrm{B}$ particles with spherical barium ferrite $\left(\mathrm{BaFe}_{12} \mathrm{O}_{19}\right)$ agglomerates. The magnetic properties of starting magnetic materials are presented in Table 1. The chemical composition of the starting $\mathrm{Nd}-\mathrm{Fe}-\mathrm{B}$ alloy is Nd: 21-25 wt.\%, Co: 3-5 wt.\%, B $<1.5$ wt.\%, Zr: 3-5 wt.\%, Fe: balance. Barium ferrite is approximately a single-phase material with $99 \%$ of $\mathrm{BaFe}_{12} \mathrm{O}_{19}$.

As a polymer matrix thermosetting epoxy system that is a combination of liquid mixture of Bisphenol $A$ and Bisphenol $F$ resins and cross linking agent (hardener) which cures fully at room temperature is used. The epoxy resin with the following properties was selected: tensile strength $\sim 58 \mathrm{MPa}$, elongation $\sim 2.8 \%$, compression strength $\sim 96 \mathrm{MPa}$, flexural strength $\sim 78$ $\mathrm{MPa}$ and density $\sim 1.2 \mathrm{~g} / \mathrm{cm}^{3}$.

Composites with varied $\mathrm{Nd}-\mathrm{Fe}-\mathrm{B} /$ barium ferrite particle content in the polymer matrices were produced by compression molding method using a lab scale press. The structure and morphology of fracture surfaces of synthesized composite materials were observed by a JEOL JSM-5800 scanning electron microscope (SEM), with an accelerating voltage of $20 \mathrm{kV}$. Fracture sample surfaces were sputtered with gold using a POLARON SC 502 sputter coater for enhanced conductivity.

A TA Instruments DMA Q800 was used to obtain dynamic mechanical data for investigated magnetic composites and pure epoxy samples. Testing was done over a temperature range from 25 to $100{ }^{\circ} \mathrm{C}$ with a temperature ramp of $3^{\circ} \mathrm{C} / \mathrm{min}$.

The magnetic properties were obtained using vibrating sample magnetometer (VSM) (EG\&G Princeton Applied Research type) at ambient temperature (300 $\mathrm{K})$. Disc shape samples with $5 \mathrm{~mm}$ radius and $3 \mathrm{~mm}$ thickness were placed parallel to vector of magnetic field. Maximum magnetic field strength and time of exposure were $2.4 \mathrm{~T}$ and $10 \mathrm{~s}$, respectively.

\section{RESULTS AND DISCUSSION}

One way of improving some physical properties of the bonded magnets is to produce hybrid magnets prepared from a mixture of two powders with different properties, e.g., the $\mathrm{Nd}-\mathrm{Fe}-\mathrm{B}$ powders with barium ferrite [11]. The addition of ferrite to the $\mathrm{Nd}-\mathrm{Fe}-\mathrm{B}$ powder decreases the temperature coefficient of coercivity (commonly known as $\beta\left[\% /{ }^{\circ} \mathrm{C}\right]$ ), which means that this type of bonded magnet can work under elevated temperatures. Also, for example, the bonded magnet has improved the mechanical properties with addition of iron powder. Further benefits of adding ferrite or iron would be cost reduction and ease of magnetization.

The synthesized hybrid magnetic composite materials correspond to mixtures of $\mathrm{Nd}-\mathrm{Fe}-\mathrm{B}$ and barium ferrite in different ratios. SEM micrographs of composite materials with epoxy matrix are presented in Figure 1. The $\mathrm{Nd}-\mathrm{Fe}-\mathrm{B}$ particles are shown as light grey platelet shape, barium ferrite as spherical light grey, and the epoxy matrix is shown as dark. Although the magnetic particles are of variable size and shape, they seem to be attached rather well to the matrix.
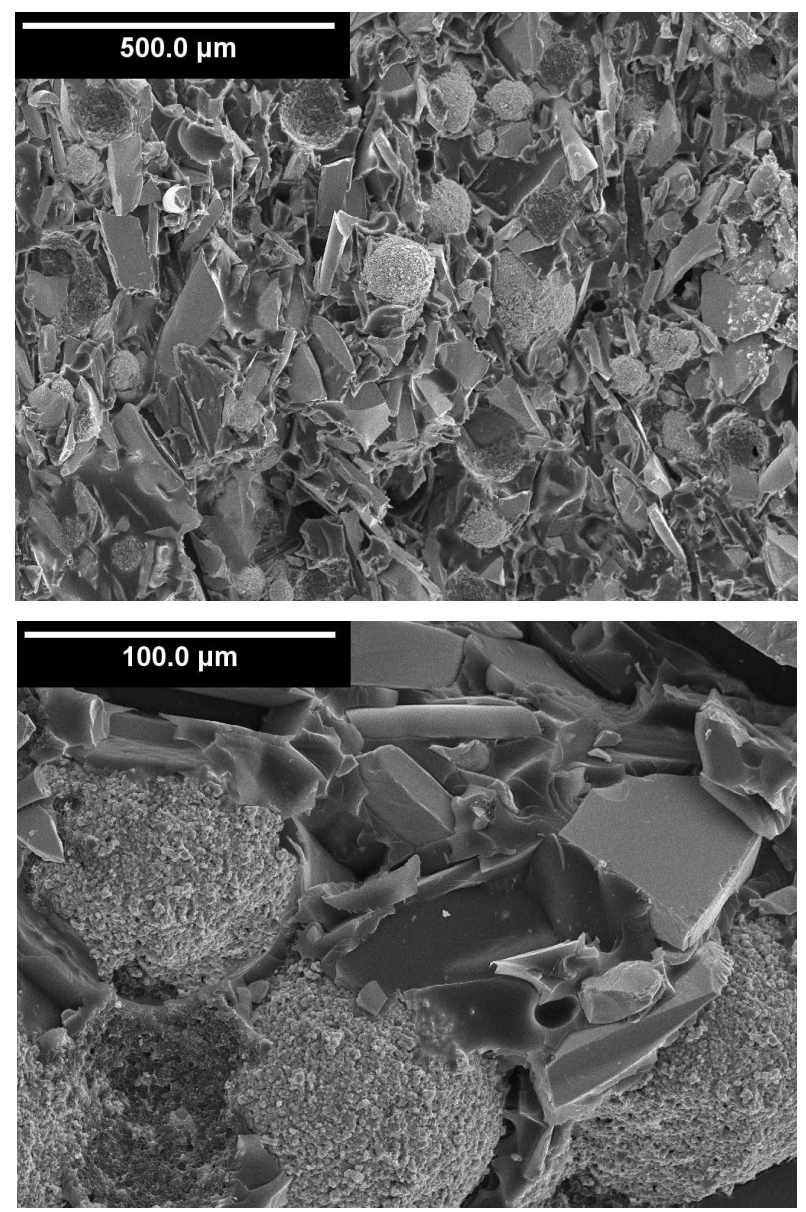

Figure 1. SEM Micrographs of hybrid magnetic composite materials with epoxy matrix.

The particle size of magnetic powder plays an important role in determining powder to binder ratio, degree of particle alignment, and magnetic and mecha-

Table 1. Magnetic properties of started magnetic materials

\begin{tabular}{lccccc}
\hline Material & Chemical formula & $B_{\mathrm{r}} / \mathrm{kG}$ & $H_{\mathrm{cb}} / \mathrm{kOe}$ & $H_{\mathrm{cj}} / \mathrm{kOe}$ & $B H_{\max } / \mathrm{MGOe}$ \\
\hline Neodymium iron boron & $\mathrm{Nd}_{11.7}(\mathrm{Fe}, \mathrm{Co})_{80} \mathrm{~B}_{8.3}$ & 8.2 & 6.0 & 8.7 & 13.1 \\
Barium ferrite & $\mathrm{BaFe}_{12} \mathrm{O}_{19}$ & 2.3 & 1.9 & 3.6 & 1.3 \\
\hline
\end{tabular}


nical properties. The packing density can be increased by mixing powder fractions of different particle size and size distribution. The optimized powder mixture has small particles filling the interparticle space between larger particles. Since the crumbled ferrite agglomerates are incorporated between bigger particles of ferrite and $\mathrm{Nd}-\mathrm{Fe}-\mathrm{B}$, they contribute to the improved dynamic mechanical properties of composite $[12,13]$.

The TG and DSC curves for epoxy resin are shown in Figure 2. TG experiments were conducted to determine the degradation temperatures, $T_{\mathrm{d}}$, of used epoxy resin. The degradation temperature indicates the temperature corresponding to the highest rate of weight loss. The results obtained by DSC method are in accordance with TG measurements. The DSC curve shows an exothermic effect which appears between 320 and $360^{\circ} \mathrm{C}$ and corresponds to the reaction of thermal degradation or decomposition of the composite materials. Small endothermic effect, illustrated as a step transition in temperature range between 45 and $50{ }^{\circ} \mathrm{C}$, is assigned to a glass transition of the epoxy resin [14].

The change of enthalpy that occurs during the thermal analyzing process decreases with increase of the concentration of added magnetic filler (i.e., with decrease of epoxy matrix content in composites), as reported previously [15]. Also, transition temperatures are shifted to higher values but remain in the same temperature range. The thermal behavior of the polymer matrix is an important parameter for bonded magnet applications due to fact that vibrations, high temperatures, aggressive environments, etc., can affect the structure of composites. Also, it is well known that sintered $\mathrm{Nd}-\mathrm{Fe}-\mathrm{B}$ magnets are applicable at temperatures from $140-160{ }^{\circ} \mathrm{C}[16]$.

The results of DMA are presented in Figure 3. For different types of composites (with the same content of epoxy resin), the values of storage modulus $E^{\prime}$ and $\tan \delta$ are compared. The material's $\tan \delta$ designates the material's ratio of viscous to elastic components, $E^{\prime \prime} / E^{\prime}$ and it is sometimes called the materials damping ability [17]. A composite material with a higher $\tan \delta$ has a higher viscous percentage than one with a lower $\tan \delta$. Therefore, the material would be more likely to absorb a vibration or impact, and disperse it throughout the material without failure. DMA results presented in Figure $3 \mathrm{~b}$ show glass transition temperatures, $T_{\mathrm{g}}$, obtained from $\tan \delta$ curves for all investigated magnetic composites. The temperatures are shifted from 52 to $57{ }^{\circ} \mathrm{C}$, probably due to the presence of small particles between plate shape $\mathrm{Nd}-\mathrm{Fe}-\mathrm{B}$ particles, which has direct impact on dynamic mechanical properties of composites. All composites have improved storage modulus compared to pure epoxy resin, while the hybrid $\mathrm{Nd}-\mathrm{Fe}-\mathrm{B} /$ barium ferrite/epoxy resin type composite had the highest value (Figure 3a).

Magnetic properties of composite materials (bonded magnets) are affected by the properties and weight (volume) ratio of the magnetic powder. It is known that bonded magnets have inferior magnetic characteristics compared to magnetic material obtained by sintering methods for example, because in bonded technology maximum density of magnetic powder cannot be

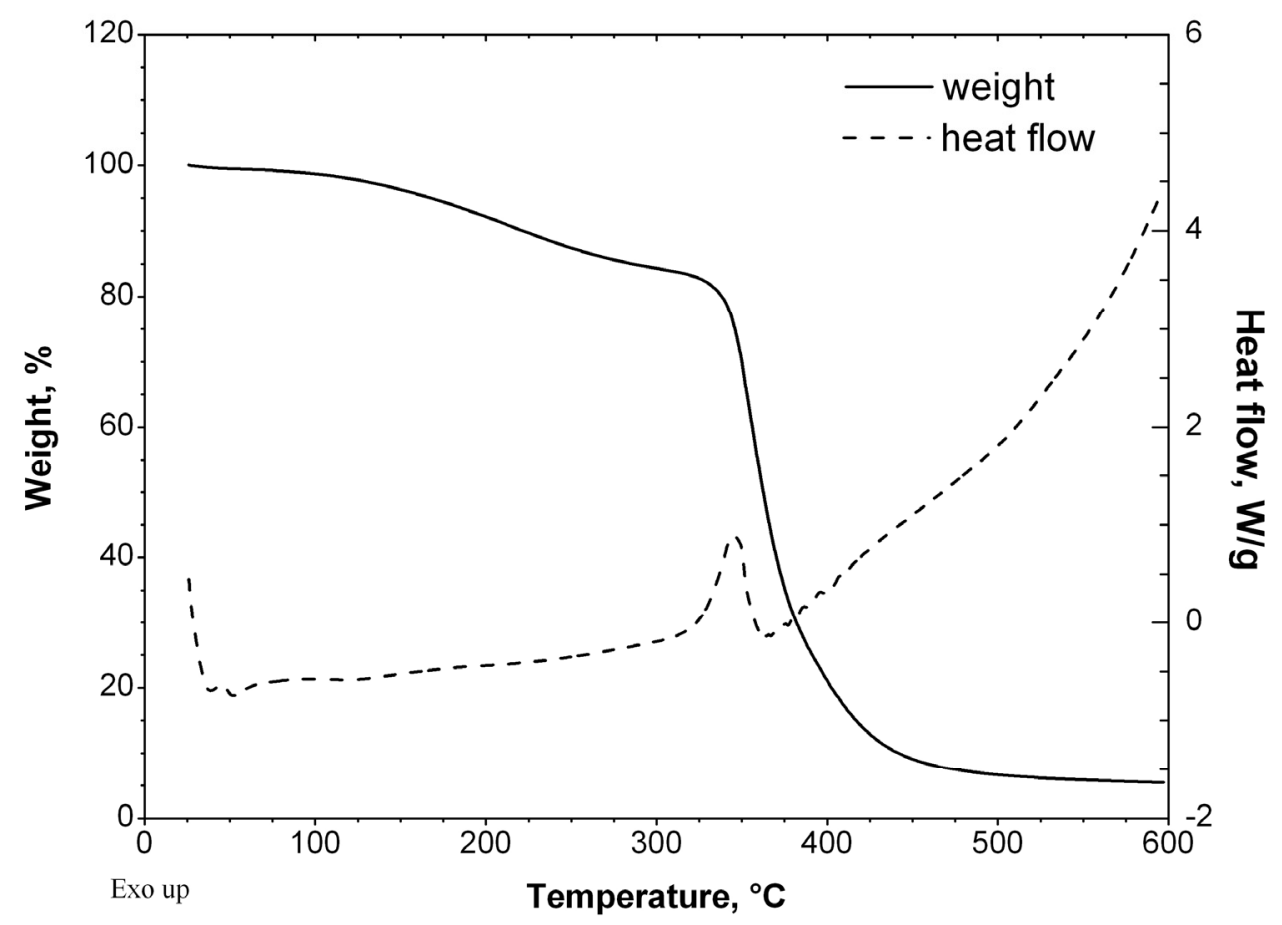

Figure 2. TG and DSC curves for epoxy resin. 

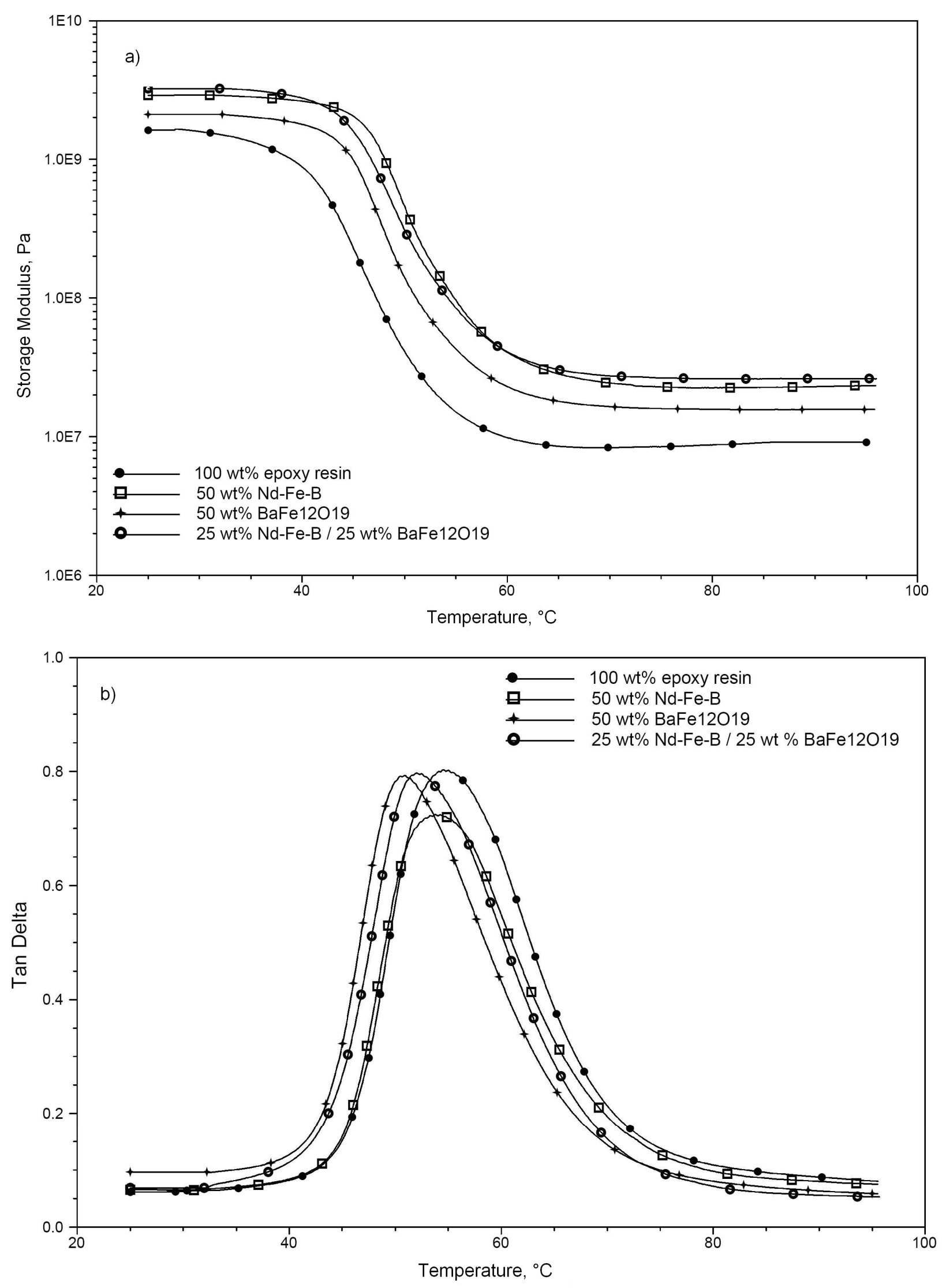

Figure 3. Nd-Fe-B/epoxy composites: a) storage modulus and b) tan $\delta$ in the function of temperature. All composites are with 50 wt.\% epoxy resin. 
achieved [18]. One of the most important characteristics of the used type of $\mathrm{Nd}-\mathrm{Fe}-\mathrm{B}$ rare-earth magnetic material is high values of remanence and coercivity, which have a direct influence on high values of maximum energy product [19]. The results of magnetic measurements for bonded $\mathrm{Nd}-\mathrm{Fe}-\mathrm{B} / \mathrm{epoxy}$ composites are presented in Figure 4. It is obvious that both percentage and composition of magnetic particles in polymer matrix have direct influence on the magnetic properties of polymer-bonded composites.

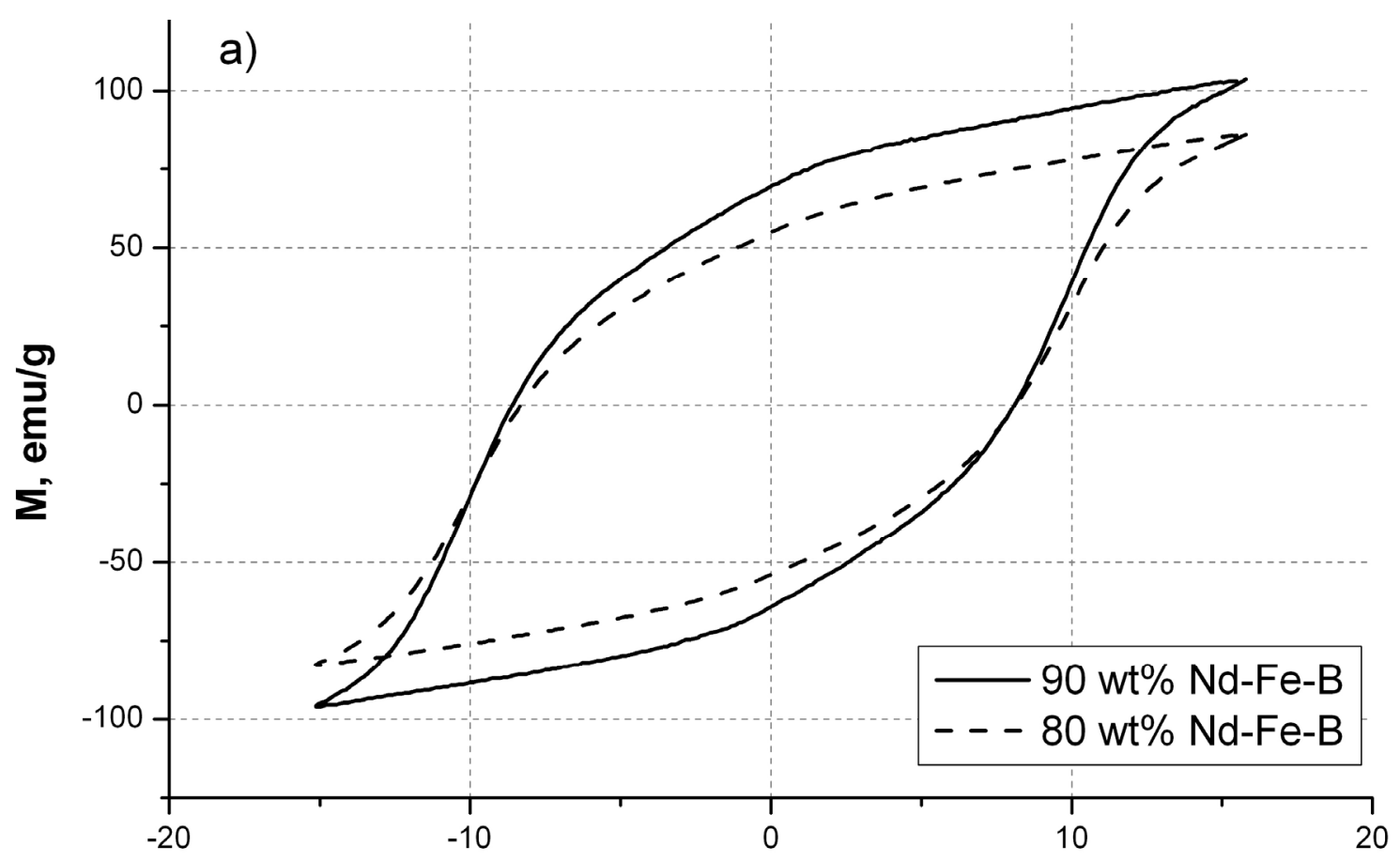

H, kOe

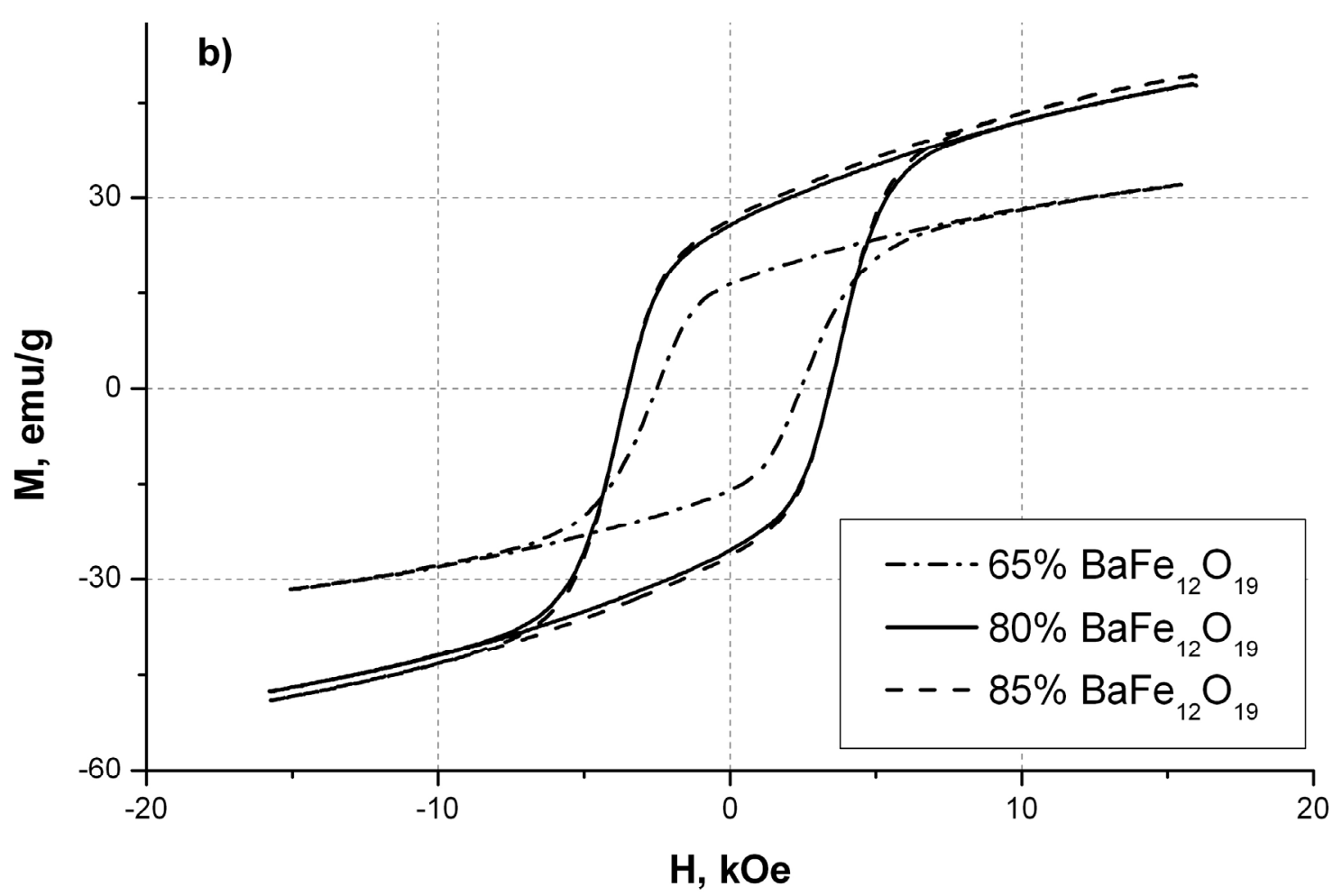

Figure 4. VSM Hysteresis loops for different types of polymer bonded composites. 


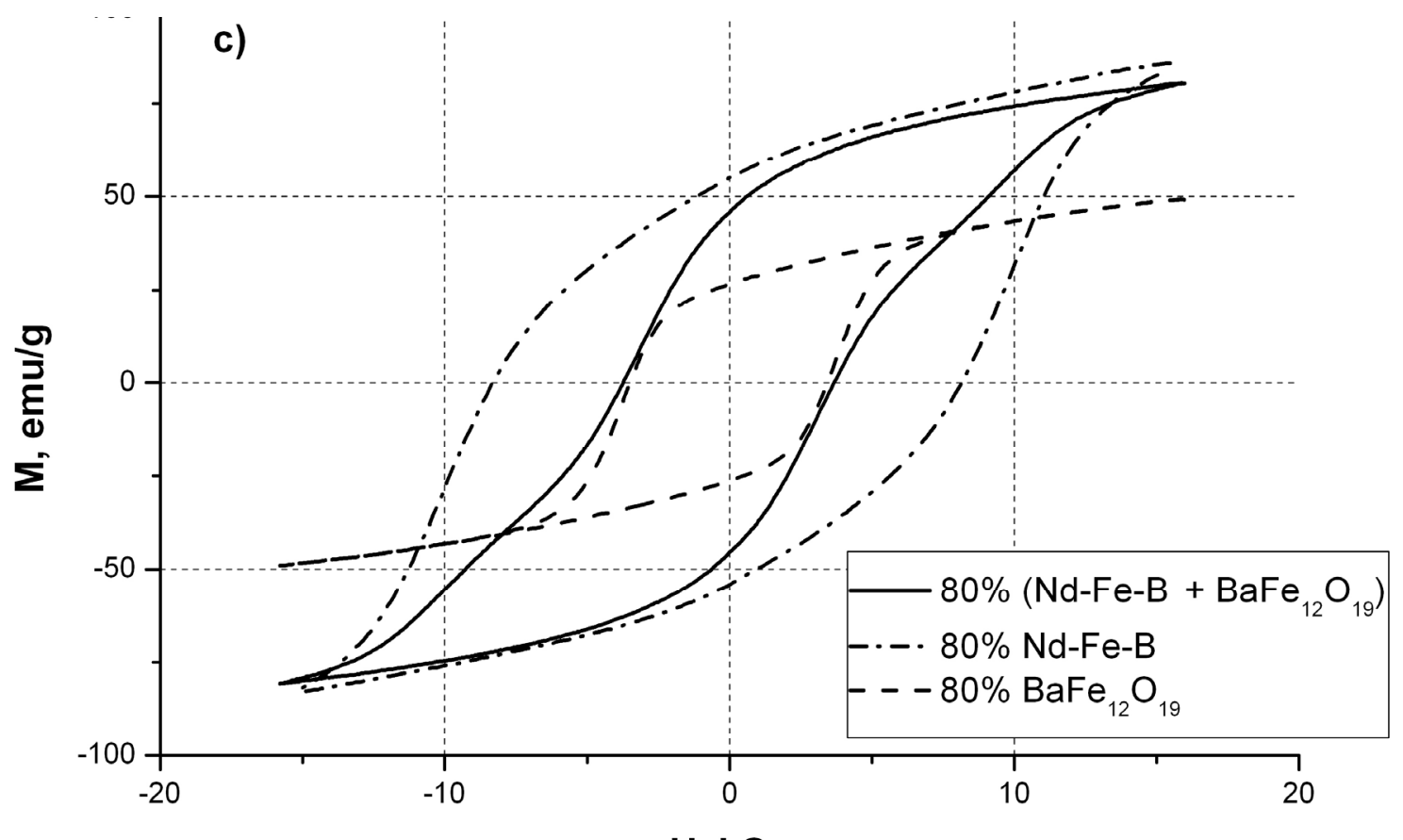

\section{$\mathrm{H}, \mathrm{kOe}$}

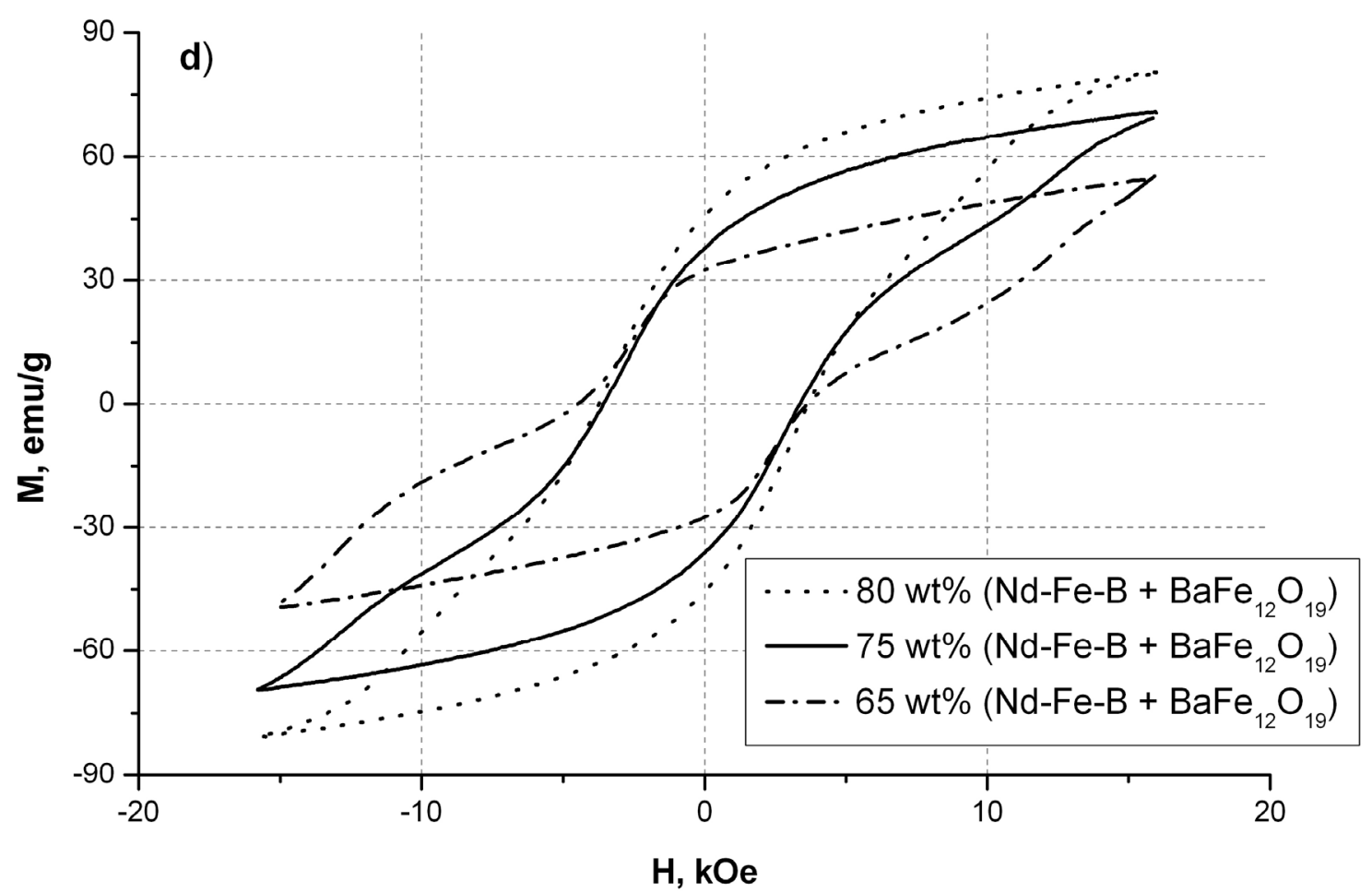

Figure 4 (continued). VSM Hysteresis loops for different types of polymer bonded composites.

Characteristic shapes of hysteresis loops for $\mathrm{Nd}-\mathrm{Fe}-\mathrm{B}$ alloys with stoichiometric $\mathrm{Nd}$ content, barium ferrite and hybrid composites ( $\mathrm{Nd}-\mathrm{Fe}-\mathrm{B} /$ barium ferrite) are presented in Figures $4 a-4 d$. All investigated curves become more constricted with decreasing content of magnetic filler. For example, magnetic properties of $\mathrm{Nd}-\mathrm{Fe}-\mathrm{B}$ composites are reduced due to the filler pre- sence of 80 and 90 wt.\% in epoxy matrix. Magnetic properties of barium ferrite are reduced compared to the $\mathrm{Nd}-\mathrm{Fe}-\mathrm{B}$ bonded magnets and hybrid composites. In the region of high magnetic field strength, hysteresis curves of barium ferrite show constant increase of magnetization with a tendency to achieve saturation. Hysteresis loops show stepped transition for all investi- 
gated hybrid magnetic composites. This shape of hysteresis practically represents a resultant of hysteresis loops of both $\mathrm{Nd}-\mathrm{Fe}-\mathrm{B}$ and barium ferrite present in a composite. The values presented in Figure 4 should be taken as approximate because the maximum field strength of VSM (2.4 T) is not sufficient for full saturation of $\mathrm{Nd}-\mathrm{Fe}-\mathrm{B}$ powders.

\section{CONCLUSION}

Hybrid materials development and utilization are economically motivated, due to fact that these materials can be produced at low cost. For example, replacing a fraction of $\mathrm{Nd}-\mathrm{Fe}-\mathrm{B}$ with less expensive barium ferrite creates a new hybrid composite. This hybrid composite shows lower intensity of magnetic energy compared to the original composite, but on the other hand, shows improved dynamic mechanical properties. In view of aforementioned facts, it could be said that investigated hybrid materials could replace existing composite materials in numerous applications. Considering the increasing interest in polymer composites and advanced analytical tools, the present study provides a useful basis and motivation for future experiments and theory development for the multifunctional components, and commercially important polymer bonded magnets.

\section{Acknowledgement}

This work has been supported by the Ministry of Education and Science of the Republic of Serbia under Projects: 34011, 45019 and 45022.

\section{REFERENCES}

[1] J.F. Herbst, $\mathrm{R}_{2} \mathrm{Fe}_{14} \mathrm{~B}$ materials: Intrinsic properties and technological aspects, Rev Mod Phys. 63 (1991) 819-898 .

[2] M. Sagawa, S. Fujimura, N. Togawa, H. Yamamoto, Y. Matsuura, New material for permanent magnets on a base of Nd and Fe, J. Appl. Phys. 55 (1984) 2083-2087.

[3] D.N. Brown, Z. Chen, P. Guschl, P. Campbell, Developments with melt spun RE-Fe-B powder for bonded magnets, J. Magn. Magn. Mater. 303 (2006) e371-e374.

[4] O. Gutfleisch, M.A. Willard, E. Brück, C.H. Chen, S.G. Sankar, J.P. Liu, Magnetic materials and devices for the 21st century: Stronger, lighter, and more energy efficient, Adv. Mater. 23 (2011) 821-842.

[5] S.R. Trout, Understanding permanent magnet materials; an attempt at universal magnetic literacy, Proceedings of EMCW 2000, Cincinnati, OH, 2000, http://spontaneousmaterials.com/Papers/CW2000.pdf

[6] I. Shyha, S.L. Soo, D. Aspinwall, S. Bradley, Effect of laminate configuration and feed rate on cutting performance when drilling holes in carbon fibre reinforced plastic composites, J. Mater. Process. Tech. 210 (2010) 1023-1034.

[7] J. Ma, J. Hu, Z. Li, N. Ce-Wen, Recent progress in multiferroic magnetoelectric composites: from bulk to thin films, Adv. Mater. 23 (2011) 1062-1087.

[8] D. Hinz, A. Kirchner, D.N. Brown, B.-M. Ma, O. Gutfleisch, Near net shape production of radially oriented NdFeB ring magnets by backward extrusion, J. Mater. Process. Tech. 135 (2003) 358-365.

[9] M.G. Garrell, A.J. Shih, B.M. Ma, E. Lara-Curzio, R.O. Scattergood, Mechanical properties of bonded Nd-Fe-B permanent magnets, J. Magn. Magn. Mater. 257 (2003) 32-43.

[10] M. Lahelin, I. Aaltio, O. Heczko, O. Söderberg, Y. Ge, S.P. Hannula, J. Seppälä, DMA testing of Ni-Mn-Ga/polymer composites. Compos. Part A: Appl. Sci. 40 (2009) 125$-129$.

[11] D. Plusa, M. Dospial, B. Slusarek, U. Kotlarczyk, Magnetization reversal mechanisms in hybrid resin-bonded $\mathrm{Nd}-\mathrm{Fe}-\mathrm{B}$ magnets, J. Magn. Magn. Mater. 306 (2006) 302-308.

[12] X.H. Zhang, W.H. Xiong, Y.F. Li, N. Song, Effect of process on the magnetic and mechanical properties of $\mathrm{Nd}-\mathrm{Fe}-\mathrm{B}$ bonded magnets, Mater. Des. 30 (2009) 1386-1390.

[13] D. Rodrigues, G.V. Concilio, F.G. Landgraf, in: F.P. Missell, V. Villas-Boas (Eds.), Proceedings of the $14^{\text {th }}$ International Workshop Rare-Earth Magnets and Their Applications, Vol. 1, 1996, Sao Paulo, Brazil, 1996, pp. 580-589 .

[14] T. Maity, B.C. Samanta, S. Dalai, A.K. Banthia, Curing study of epoxy resin by new aromatic amine functional curing agents along with mechanical and thermal evaluation, Mat. Sci. Eng., A 464 (2007) 38-46.

[15] A. Grujić, J. Stajić-Trošić, M. Stijepović, J. Stevanović, R. Aleksić, in: Metal, Ceramic and Polymeric Composite for Various Uses, J. Cuppoletti (Ed.), InTech, Croatia, 2011, pp. 505-524.

[16] K.J. Strnat, Modern permanent magnets for applications in electro-technology, Proceedings of the IEEE, Vol. 78, No. 6, 1990, p. 923, doi:10.1109/5.56908.

[17] K.P. Menard, Dynamic Mechanical Analysis: A Practical Introduction, CRC Press LLC, Boca Raton, FL, 1999.

[18] X.H. Zhang, W.H. Xiong, Y.F. Li, N. Song, Effect of process on the magnetic and mechanical properties of $\mathrm{Nd}-\mathrm{Fe}-\mathrm{B}$ bonded magnets, Mater. Design. 30 (2009) 1386-1390.

[19] D. Goll, H. Kronmüller, High-performance permanent magnets, Naturwissenschaften 87 (2002) 423-438. 


\section{IZVOD}

\section{HIBDRIDNI Nd-Fe-B/BARIJUM-FERIT MAGNETNI MATERIJALI SA EPOKSI MATRICOM}

Aleksandar P. Stajčić ${ }^{1}$, Jasna T. Stajić-Trošić ${ }^{1}$, Aleksandar S. Grujić ${ }^{1}$, Mirko Z. Stijepović ${ }^{2}$, Nada L. Lazić ${ }^{4}$, Tomáš Žák ${ }^{5}$, Radoslav R. Aleksić ${ }^{3}$

${ }^{1}$ Univerzitet u Beogradu, Institut za hemiju, tehnologiju i metelurgiju, Beograd, Srbija

${ }^{2}$ Texas A\&M University at Qatar, Department of Chemical Engineering, Qatar

${ }^{3}$ Univerzitet u Beogradu, Tehnološko-metalurški fakultet, Beograd, Srbija

${ }^{4}$ Institut za opštu i fizičku hemiju, Beograd, Srbija

${ }^{5}$ Institute of Physics of Materials AS CR, Brno, Czech Republic

(Naučni rad)

Istraživački trend u oblasti polimerom vezanih (bonded) Nd-Fe-B magnetnih materijala se reflektuje kroz razvoj bonded hibridnih kompozita sa poboljšanim dinamičko-mehaničkim svojstvima i primetno nižoj ceni zbog zamene skupe $\mathrm{Nd}$ Fe-B legure jeftinijim magnetnim materijalima (ferit) uz postizanje zadovoljavajućih vrednosti maksimalne magnetne energije. Cilj ovog rada je da ukaže i predvidi uticaj različitog sadržaja Nd-Fe-B i/ili barijum feritnih čestica na morfološka, dinamičko mehanička i magnetna svojstava bonded magneta. Posmatrane su i analizirane interakcije između magnetnih prahova, kao i interakcije između magnetnih prahova i polimernog veziva i njihov uticaj na finalna svojstva bonded magneta. Za ispitivanje magnetnog ponašanja korišćen je vibraconi magnetometar (VSM). Različite veličine i oblici dobijenih histerezisnih krivih su poređeni i korišćeni za predviđanje svojstava ispitivanih kompozitnih materijala. Homogena raspodela magnetnih čestica u polimernoj matrici je potvrđena korišćenjem skenirajućeg elektronskog mikroskopa (SEM). Elastična svojstva i svojstvo prigušenja oscilacija ispitivano je korišćenjem dinamičko mehaničke analize (DMA) koja ukazuje na poboljšana svojstva kod hibridnih kompozita.

Ključne reči: $\mathrm{Nd}-\mathrm{Fe}-\mathrm{B} \bullet$ Kompoziti Bonded magneti $\bullet \mathrm{DMA} \bullet \mathrm{VSM}$ 